\title{
Lime-phosphate interactions on a Kaipara clay soil in Northland
}

\author{
M.B. O'CONNOR ${ }^{1}$ B.J. HUNT ${ }^{2}$ and K.W. PERROTT ${ }^{3}$ \\ 19 Radford Place, Hamilton \\ ${ }^{2}$ Northland Pastoral Research Ltd, 4 Barclay Place, Whangarei \\ ${ }^{3} 61$ A Flynn Road, Hamilton \\ oconnormc@actrix.co.nz
}

\begin{abstract}
The Kaipara clay soils and associated soil types occupy some 36000 ha in Northland. The soils are naturally high in $\mathrm{P}$ and $\mathrm{P}$ fertilisers have been used sparingly in the past but with increasing farming intensity a fall in soil Olsen P values (to $<20$ ) is occurring and responses to $\mathrm{P}$ fertilisers are becoming more common. Lime is widely used. In December 1996, a field trial, conducted over 6 years, was established on a Kaipara clay soil near Ruawai. The first phase (1996-1999) consisted of six rates of $\mathrm{P}(0,20,40,60,80,100 \mathrm{~kg} \mathrm{P} / \mathrm{ha})$ with or without lime at $5 \mathrm{t} /$ ha applied once. The initial $\mathrm{pH}$ was 5.8 and Olsen P was 16. Results indicated a marked rates response to $\mathrm{P}$ without lime but with lime a marked Psparing effect occurred equivalent to $50-60 \mathrm{~kg} \mathrm{P} / \mathrm{ha}$. The effect was consistent over 3 years. An explanation for this finding is due to lime improving plant growth probably by $\mathrm{N}$ mineralisation and $\mathrm{N}$ uptake, thus giving improved root growth and allowing those roots to explore a greater volume of soil and absorb more P. Plant chemical analyses and soil $\mathrm{P}$ fractionation studies indicated that more $\mathrm{P}$ was being taken up by plants on the lime/no P plots. The second phase (2000-2003) involved splitting plots and applying additional lime to some to give a $\mathrm{pH}$ range from 5.6-7.0. Results indicated no benefit to increasing $\mathrm{pH}$ above 6.0 but there was a suggestion that the reapplication of lime itself was beneficial. The $P$ sparing effect of lime will best be utilised where soil Olsen P levels remain above 20.
\end{abstract}

Keywords: P-sparing effect, lime, phosphate, Kaipara clay

\section{Introduction}

Northland soils in general respond well to inputs of $\mathrm{P}$ and lime. The Kaipara clay soils and associated soil types occupy some 36,000 ha in Northland (Roberts \& Jarman 1979). These are soils of the flood plains and are formed from alluvium derived from sedimentary parent material. They are winter wet and require drainage but potentially are high producing soils (Gibbs 1964). The soils are naturally high in $\mathrm{P}(\mathrm{Olsen} \mathrm{P}>30)$ and $\mathrm{P}$ fertilisers have been used sparingly in the past. Lime however is seen as being very important and many farmers are regular users even where $\mathrm{pH}$ is in the optimum range of 5.8-6.0. With increasing farming intensity a fall in soil Olsen $\mathrm{P}$ values is being experienced.

This paper presents results from a 6-year field trial, together with a laboratory study, investigating the ongoing requirements for fertiliser and lime on a Kaipara clay soil near Ruawai.

\section{Methods}

\section{Field Trial Phase 1: 1996-1999}

In December 1996, a field trial was laid down in an old, permanent ryegrass-clover pasture at Ruawai on a Kaipara clay soil with $\mathrm{pH} 5.8$ and Olsen P 16. The trial paddock was in a dairy farm rotation but the trial plots were fenced from grazing. The trial consisted of six rates of $\mathrm{P}(0,20,40,60,80,100 \mathrm{~kg} \mathrm{P} / \mathrm{ha} /$ annum $)$ with or without $5 \mathrm{tlime} / \mathrm{ha}$ applied once with four replications to give 48 plots. Plot size was $6 \mathrm{~m}^{2}(4 \times 1.5 \mathrm{~m})$. P was applied as superphosphate with a base dressing of $\mathrm{K}, \mathrm{S}$ (40\% elemental S), Cu and Mo. Measurements included pasture production on a continuous basis with two mower strips taken per plot, annual soil tests $(\mathrm{pH}$ and Olsen $\mathrm{P}$ ) and herbage chemical analysis (\% N and $\mathrm{P})$.

\section{Field trial Phase 2: 2000-2003}

Trial plots were split in half, one half received additional lime to give a range in $\mathrm{pH}(5.6,6.1,6.5$ and 7.0$)$ while the other half was left in the original state. The aim was to determine whether an increase in $\mathrm{pH}$ (above 6.1) would enhance a P-sparing effect apparent in Phase 1. The range in $\mathrm{pH}$ levels was achieved by applying $9 \mathrm{t} / \mathrm{ha}$ lime (split $4 \mathrm{t}$ plus $5 \mathrm{t}$ ) to plots which had a $\mathrm{pH} 5.6$ and 6.1 from the previous treatments in phase 1. A further $2 \mathrm{t}$ and $5 \mathrm{tlime/}$ ha respectively was applied in June 2001 to achieve the projected $\mathrm{pH}$ levels. All plots received inputs of $\mathrm{P}$ as for phase 1 .The aim was to see whether increasing the $\mathrm{pH}$ to above optimum levels would be of benefit in terms of increased pasture production.

\section{Laboratory study: 2003-2004}

Phosphorus fractionation studies (Perrott et al 1989) were carried out at AgResearch, Ruakura on soil samples taken in November 2003 from the field trial's half plots which were still in their original state from phase 1 . These samples represented the six rates of $P$ with and without lime (5 t/ha) plots applied in Phase 1, 7 years earlier. 
Table 1 Pasture production 1996-1999 (t DM/ha/annum).

\begin{tabular}{|c|c|c|c|c|c|c|}
\hline \multirow[b]{2}{*}{ Rates of $\mathrm{P}$} & \multicolumn{2}{|c|}{ 1996/97 } & \multicolumn{2}{|c|}{$1997 / 98$} & \multicolumn{2}{|c|}{ 1998/99 } \\
\hline & No Lime & Lime & No Lime & Lime & No Lime & Lime \\
\hline 0 & 9.37 & 10.46 & 9.17 & 11.04 & 9.02 & 12.12 \\
\hline 20 & 10.63 & 10.16 & 10.00 & 10.94 & 10.48 & 11.35 \\
\hline 40 & 10.52 & 10.65 & 9.86 & 10.59 & 10.54 & 11.28 \\
\hline 60 & 10.99 & 10.95 & 10.78 & 11.39 & 10.44 & 11.80 \\
\hline 80 & 11.32 & 11.40 & 10.69 & 10.96 & 11.11 & 10.74 \\
\hline 100 & 11.34 & 10.95 & 11.45 & 10.52 & 11.35 & 10.66 \\
\hline SED & \multicolumn{2}{|c|}{0.441} & \multicolumn{2}{|c|}{0.558} & \multicolumn{2}{|c|}{0.664} \\
\hline
\end{tabular}

\section{Results and Discussion}

\section{Field trial Phase 1: 1996-1999}

Annual pasture production ( $\mathrm{t} \mathrm{DM} / \mathrm{ha} /$ year) from the $\mathrm{Px}$ $\mathrm{L}$ trial over 3 years is shown in Table 1 . In the absence of lime there was a rates response to $\mathrm{P}$. This was to be expected given the low soil Olsen P (16) of the site. In the presence of lime, however, the $\mathrm{P}$ response disappeared. This was consistent over the 3 years. A typical result is shown in Figure 1 using 1997/98 as an

Figure 1 Pasture production responses to lime and $P$ in $1997 / 98$.

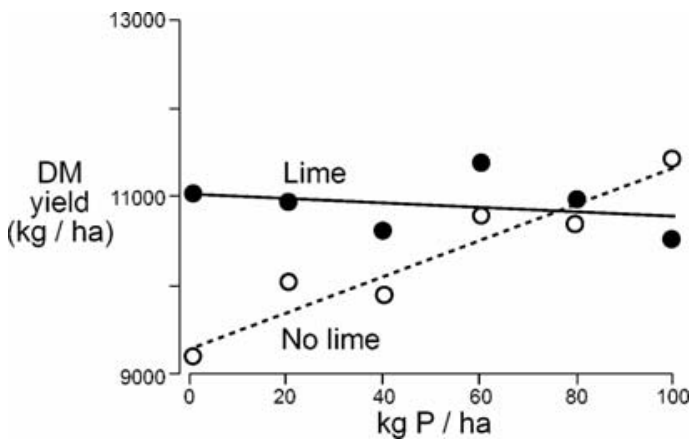

example. The lime, no P plots showed a yield response equivalent to $50-60 \mathrm{~kg} \mathrm{P} / \mathrm{ha}$. This is of interest given that the $\mathrm{pH}$ at 5.8 was within the optimum range of 5.8-6.0 for pasture production (Roberts et al. 1999). Lime then was having a strong P-sparing effect.

There is evidence from a pasture cut taken in November 1998 that percent $\mathrm{P}$ was higher on the lime/ no P plots compared with the no lime/no P plots $(0.41 \%$ versus $0.36 \%$ ) indicating that additional $\mathrm{P}$ was getting into the plants on those plots. On the other hand, Olsen P values were very similar over 3 years on the no lime and lime plots irrespective of $\mathrm{P}$ rate (Table 2) indicating that no

Table 2 Average Olsen P values 1996-1999.

\begin{tabular}{|c|c|c|c|c|c|c|}
\hline & \multicolumn{6}{|c|}{ Rates of $\mathrm{P}$ (kg P/ha/annum) } \\
\hline & 0 & 20 & 40 & 60 & 80 & 100 \\
\hline No lime & 13 & 15 & 21 & 24 & 31 & 32 \\
\hline Lime & 15 & 19 & 26 & 26 & 32 & 35 \\
\hline
\end{tabular}

soil $\mathrm{P}$ release was occurring as a result of liming.

Soil $\mathrm{pH}$ fell from 5.8 to 5.6 on the no lime plots and from 6.4 to 6.1 on the lime plots from 1997 to 1999 . The drop in $\mathrm{pH}$ was approximately 0.1 units/year indicating an input of the equivalent of $1 \mathrm{t} / \mathrm{ha}$ /annum of lime was needed to maintain $\mathrm{pH}$.

\section{Field trial Phase 2: 2000-2003}

After 12 months the reapplication of lime ( $9 \mathrm{t} / \mathrm{ha}$ ) to half the previous plots was only partially successful in attaining the projected $\mathrm{pH}$ values of 5.6, 6.1, 6.5 and 7.0. Actual $\mathrm{pH}$ levels attained were 5.6, 5.9, 6.1, 6.4 respectively. By June 2003, and following a further $2 \mathrm{t}$ or $5 \mathrm{t}$ lime/ha in 2001, pH levels were 5.5, 5.9, 6.6 and 6.9 respectively and close to the projected values.

Pasture production over the 3 years is shown in Table 3. There was no benefit to increasing the $\mathrm{pH}$ above 6.1. What appeared to be of some benefit was the actual reapplication of lime itself irrespective of $\mathrm{pH}$ (see projected $\mathrm{pH} 6.5$ and 7.0 values). The differences however were not statistically significant.

Table 3 Pasture production (t DM/ha/annum) with increasing $\mathrm{pH}, 2000-2003$.

\begin{tabular}{|c|c|c|c|c|c|}
\hline \multirow{2}{*}{ Year } & \multicolumn{4}{|c|}{$\mathrm{pH}$} & \multirow{2}{*}{ SED } \\
\hline & 5.6 & 6.1 & $6.5^{1}$ & $7.0^{1}$ & \\
\hline $2000 / 01$ & 6.33 & 6.39 & 6.52 & 6.52 & 161 \\
\hline 2001/02 & 12.14 & 12.61 & 12.92 & 13.00 & 379 \\
\hline $2002 / 03$ & 9.19 & 9.56 & 9.29 & 9.40 & 338 \\
\hline
\end{tabular}

${ }^{1}$ lime applied to half plots. Final pHs 6.6 and 6.9

In June 2002, pasture was analysed for percent P. On the plots where lime was reapplied without $P$, percent $P$ in the herbage increased significantly $(0.32,0.31,0.38$, 0.38 ; SED 0.016) with the increasing $\mathrm{pH}$ levels. This suggests that the reapplication of lime itself may have been the trigger for a continuing P-sparing effect rather than the actual $\mathrm{pH}$ itself (in the range 5.6-6.9).

Marked $P$ responses continued over the 3 years (Table 4) with maximum benefit occurring between $40-60 \mathrm{~kg}$ $\mathrm{P} / \mathrm{ha}$. By this stage Olsen P levels on the control plots had declined to 11-12 and marked P responses would be expected (Roberts et al. 1999). 
Table 4 Pasture production (t DM/ha/annum) with increasing $\mathrm{P}$ rate, 2000-2003.

\begin{tabular}{|c|c|c|c|c|c|c|c|}
\hline \multirow[t]{2}{*}{ Year } & \multicolumn{6}{|c|}{ Rates of $\mathrm{P}$ ( $\mathrm{kg} \mathrm{P} / \mathrm{ha} /$ annum) } & \multirow[t]{2}{*}{ SED } \\
\hline & 0 & 20 & 40 & 60 & 80 & 100 & \\
\hline $2000 / 01$ & 5.76 & 6.18 & 6.49 & 6.82 & 6.60 & 6.78 & 243 \\
\hline $2001 / 02$ & 11.90 & 12.30 & 12.40 & 13.02 & 13.13 & 13.24 & 612 \\
\hline $2002 / 03$ & 8.70 & 8.62 & 10.05 & 9.35 & 9.45 & 9.98 & 542 \\
\hline
\end{tabular}

Percent $\mathrm{N}$ in the herbage was measured on seven occasions between September 2001 and July 2003. On five occasions, percent $\mathrm{N}$ increased in the herbage on the limed plots compared with the no lime plots (data not presented). In three NZ studies, Wheeler and O'Connor (1998) found that $\mathrm{N}$ mineralisation following the application of $5 \mathrm{t} / \mathrm{ha}$ lime contributed $25-50 \mathrm{~kg} \mathrm{~N} /$ ha over 2 years. The increase in $\mathrm{N}$ mineralisation has been associated with lime increasing microbial activity (Edmeades et al. 1981).The effects of lime on microbial activity and hence $\mathrm{N}$ mineralisation may have been important in causing the responses measured in the current study.

\section{Laboratory study}

Results from $\mathrm{P}$ fractionation of soil samples from the Phase 1 trial are shown in Figures 2 and 3. Alkaline $P_{I}$ (Al and Fe P) increased across rates of P (Fig. 2) while acid $P_{I}$ (apatite) showed only a slight increase from accumulation of unacidulated rock phosphate. Aluminium and $\mathrm{Fe} \mathrm{P}$ forms are plant available. Where lime was applied there was a decrease in alkaline $\mathrm{P}_{\mathrm{I}}$ fractions in the soil (Fig. 3).This suggests the $\mathrm{Al}$ and $\mathrm{Fe} \mathrm{P}$ fractions were being taken up by the pasture, hence the decline in the soil. This is supported by the increase in percent $P$ in herbage noted on the lime/no P plots (see Field trial phase 2 above). There was no change in the organic $P$ fraction between lime and no lime samples (data not presented) indicating that lime was not mineralising organic P.

\section{Conclusions}

A 6-year trial on a Kaipara clay soil at an Olsen P of 16 in Northland clearly showed a P-sparing effect of lime as well as a strong $\mathrm{P}$ response in pasture production. Liming produced a marked P-sparing effect which substituted for approximately $50-60 \mathrm{~kg} \mathrm{P} / \mathrm{ha}$. It is suggested that one of the main reasons for this was that lime was mineralising $\mathrm{N}$ in this soil, hence allowing increased plant growth which in turn allowed roots to explore a greater volume of soil and absorb more $\mathrm{Al}$ and Fe P. An improved moisture status as a result of liming may also be a factor in this effect (Wheeler \& O'Connor 1998). There was no evidence for lime releasing $P$ directly or making P more available. It is further suggested that it is the reapplication of lime which is
Figure 2 Alkaline and acid $\mathrm{P}_{\mathrm{i}}$ across rates of $\mathrm{P}$.

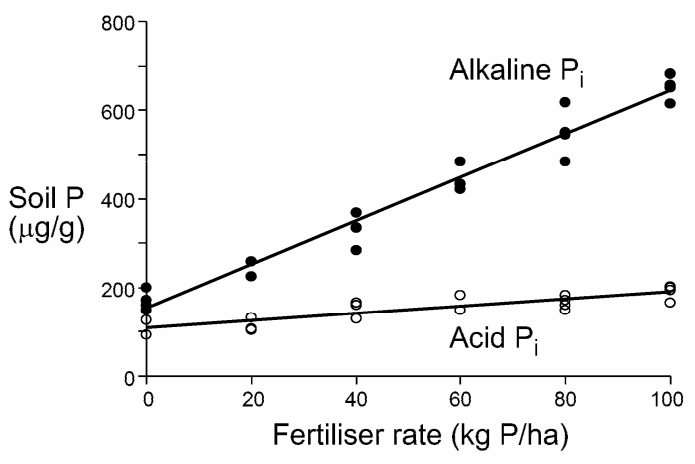

Figure 3 Changes in soil $\mathrm{P}_{\mathrm{i}}$ fractions as a result of liming. $\left(\mathrm{NaOH}-\mathrm{P}_{\mathrm{i}}+\mathrm{NaHCO}_{3}-\mathrm{Pi}+\mathrm{NaCl}-\mathrm{P}_{\mathrm{i}}=\right.$ Alkaline $\mathrm{P}_{\mathrm{i}}$ ).

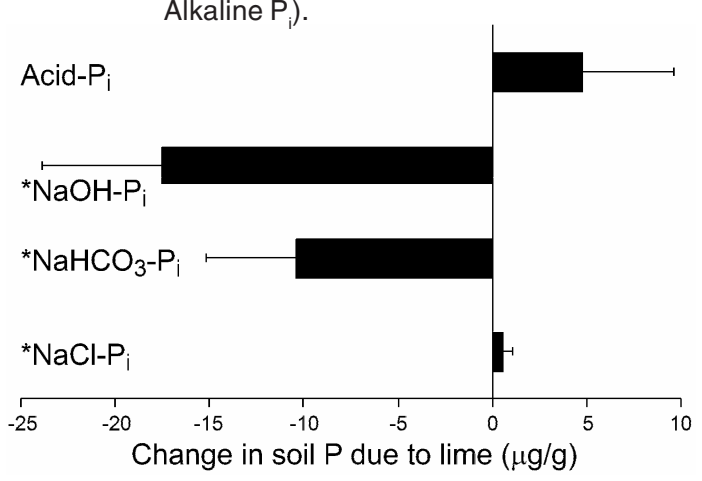

likely to be continuing to enhance the process of $\mathrm{N}$ mineralisation and ongoing P-sparing effect rather than the achievement of a particular $\mathrm{pH}$. Anecdotal evidence from good farmers in the district supports this contention. However the authors recommend farming at the optimum $\mathrm{pH}(5.8-6.0)$ on these heavy clay soils.

\section{Practical implications}

On Kaipara clay and related soil types the results from this trial indicate a P sparing effect of lime. Such P will substitute for fertiliser $\mathrm{P}$ in the short term but once soil $\mathrm{P}$ reserves are mined below Olsen $P 20$ then both fertiliser $\mathrm{P}$ and lime will be required. Where Olsen P levels remain above 30 the regular use of lime will provide a $\mathrm{P}$ sparing effect obviating the need for fertiliser $\mathrm{P}$ applications. There may be merit in a "little and often" lime application although this aspect needs more 
definitive work. It is emphasised that these results apply only to the Kaipara clay and related soil types of Northland.

\section{ACKNOWLEDGEMENTS}

The authors gratefully acknowledge the farmer Tony Oud of Ruawai for the use of his land for the trial and his help and enthusiasm over 6 years. We are also grateful to the Northland Lime Millers Association who provided annual funding over the whole trial period ably supported by Ballance Agri Nutrients Ltd (for 3 years) and Ravensdown Fertiliser Ltd (for 3 years). Thanks are also due to Martin Kear who undertook the laboratory work at AgResearch, Ruakura.

\section{REFERENCES}

Edmeades, D.C.; Judd, M.; Sarathchandra, S.U. 1981.The effect of lime on nitrogen mineralization as measured by grass growth. Plant and Soil 60: 177183.

Gibbs, H.S. 1964. Soils of Northland. Reprinted from National Resources Survey, Part 111-Northland Region. Compiled by the Town and Country Planning Branch, Ministry of Works.

Perrott, K.W.; Maher, F.M.; Thorrold, B.S. 1989. Accumulation of phosphorus fractions in yellowbrown pumice soils. New Zealand Journal of Agricultural Research 32: 53-62.

Roberts, O.T.; Jarman, S.M. 1979. Areas of soils of the North Island New Zealand. NZ Science Report 40.

Roberts, A.H.C.; Morton, J.D. 1999. Fertiliser use on New Zealand dairy farms. Fertiliser Manufacturers Research Association, Auckland. 36 pp.

Wheeler, D.M.; O’Connor, M.B. 1998. Why do pastures respond to lime? Proceedings of the New Zealand Grassland Association 60: 57-61. 